برداشت و درك ذهنى مصرف كنند مطالعه كيفى در تهران

سعيد زارع بيدكى '، جلال الدين ميرزاى رزاز ‘ّ آرزو حقيقيان رودسرى

ا - دانش آموخته كارشناسى ارشد علوم تغذيه، دانشكده علوم تغذيه و صنايع غذايى، انستيتو تحقيقات تغذيهاى و صنايع غذايى كشور، دانشكاه علوم يزشكى شهيد بهشتى، تمران، ايران

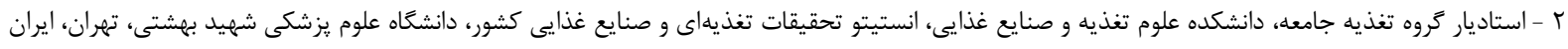

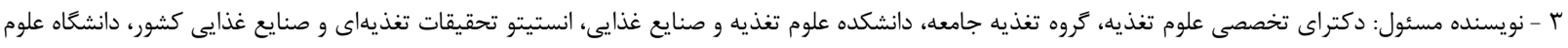
يزشكى شهيد بهشتى، تهران، ايران. يست الكترونيكى:

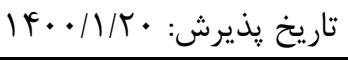

१९/9/10 تاريخ دريافت

جكيده

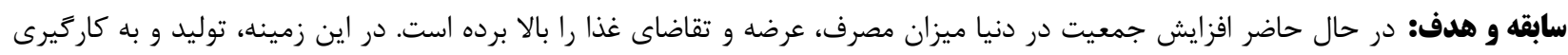

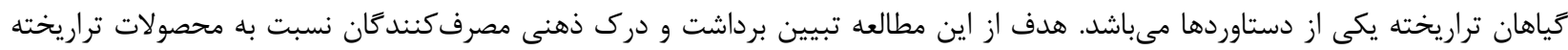

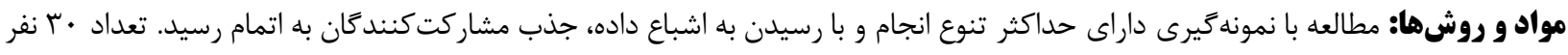

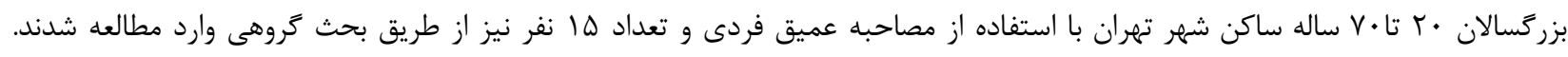

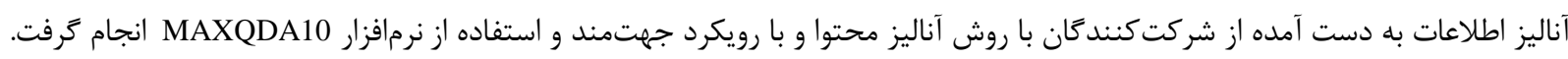

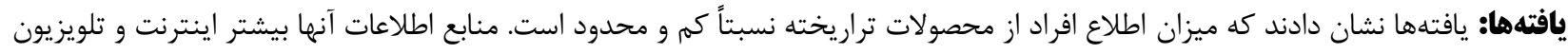

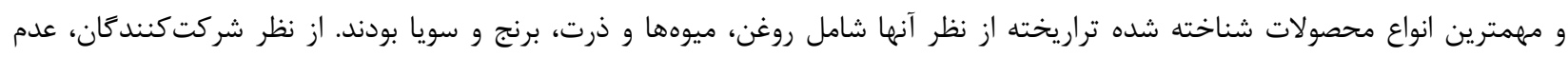

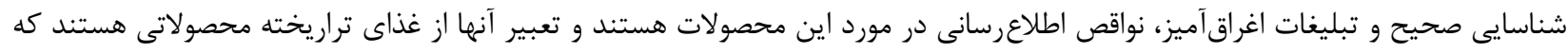

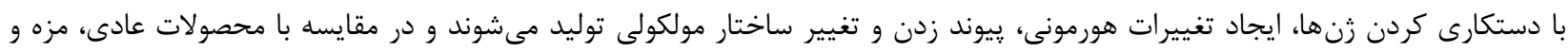

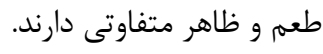

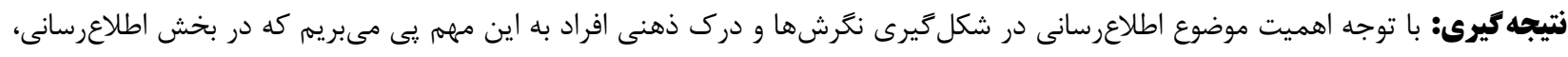

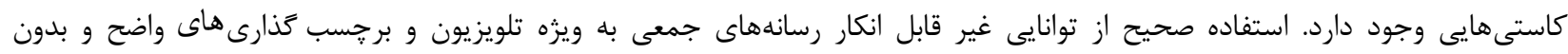

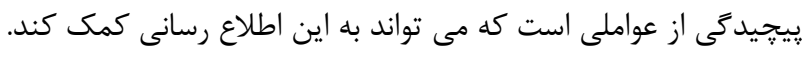

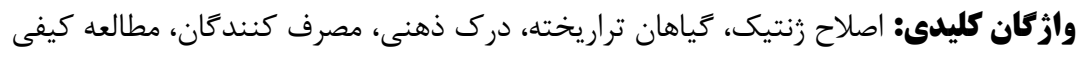

فناورى، روش هاى ييشرفتهاى را تقريباً در تمامى زمينهها براى

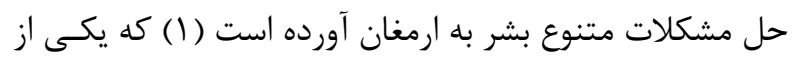

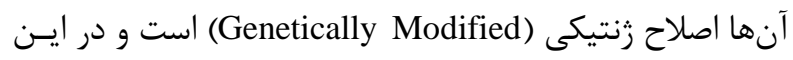

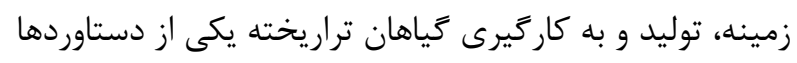

كَياهان تراريختـه محصـولاتى هسـتند كـهـ بـا اسـتفاده از

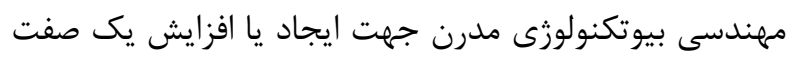

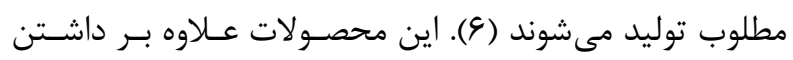

\section{مقدمه}

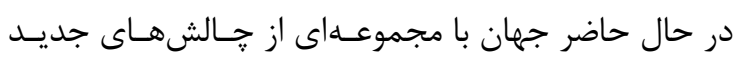

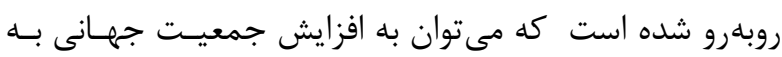

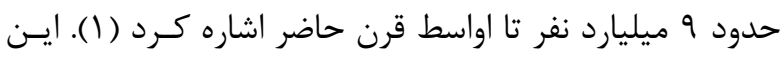

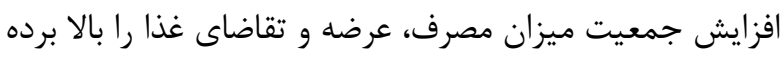

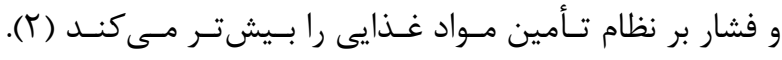

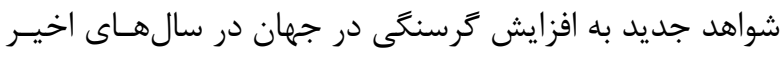

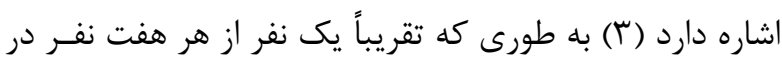

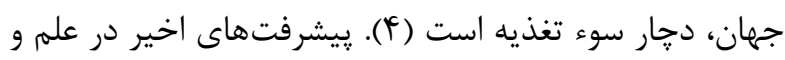


و مخالف اين فناورى شكل كرفته اسـت كـه در ابعـاد مختلـف دلايل خود را بيان مى كنند (r (I).

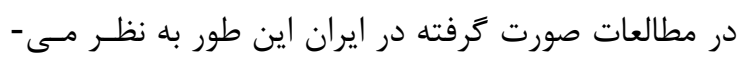

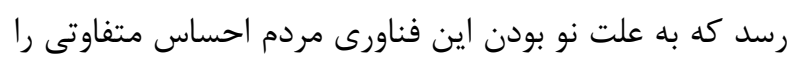

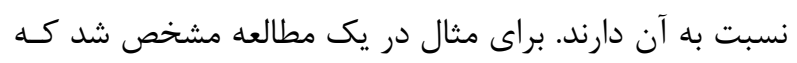

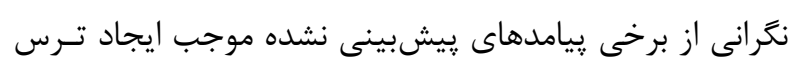

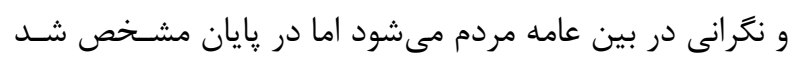
نخرش كلى نسبت به محصولات غذايى تراريخته تقريباً مثبـت

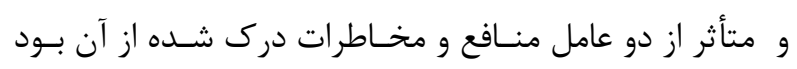

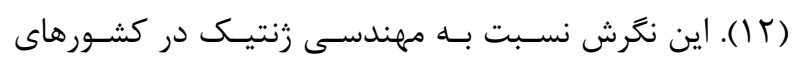

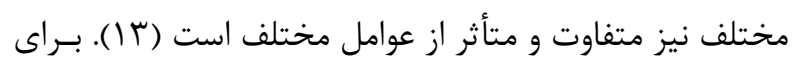

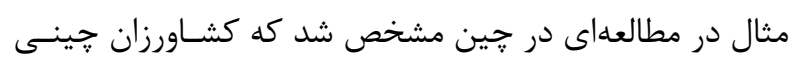

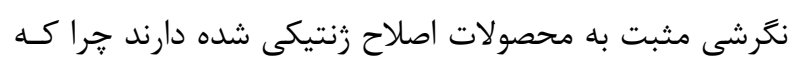

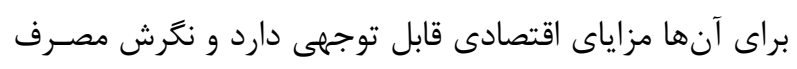
كنندگًان اين محصولات با توجه مناطق محل سكونت متفاوت بوده، به طورى كه اين نخرش در مناطق توسعهيافته مثبـت بـتـر

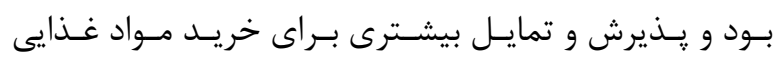
تراريخته نسبت به مصرف كنند

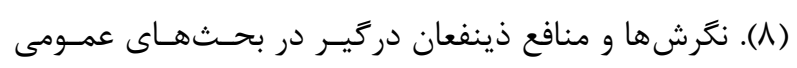

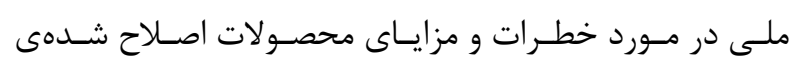

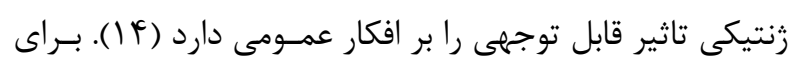

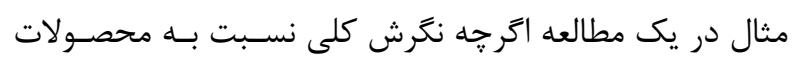

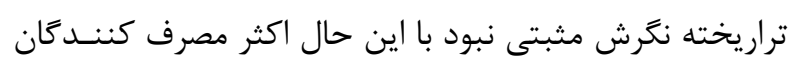

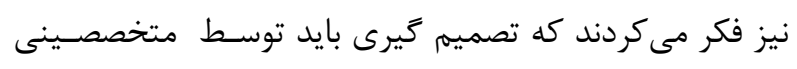

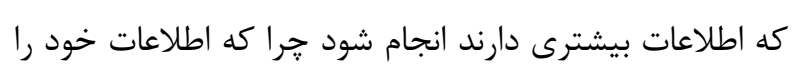
در مورد دستكارى زنتيكى كافى نمى دانستند (ه (1).

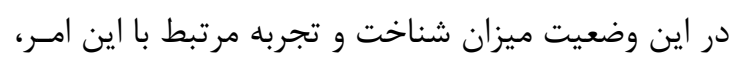
درك ذهنى عامه مردم و گروههاى مختلف اجتماعى به عنـوان

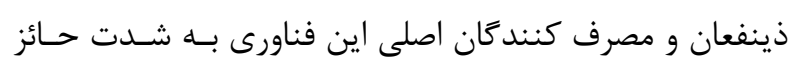

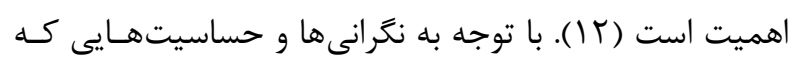
در اين زمينه در ميان مصرف كنند مان وجود دارد هدف از اين

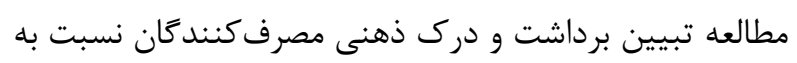

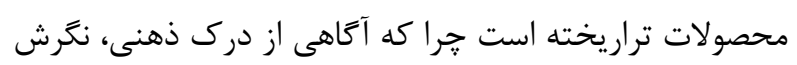
و تجربياتى كه مصرفكنـد مان در مورد اين محصولات دارنـد،

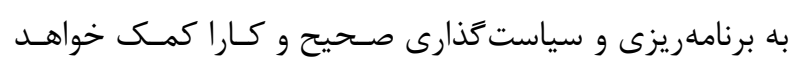

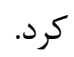

\section{• - مواد و روشها}

بر اساس هدف مطالعه، جهت جمعآورى دادهها از مطالعه

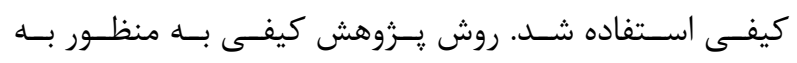

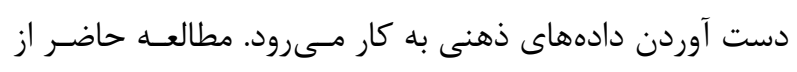

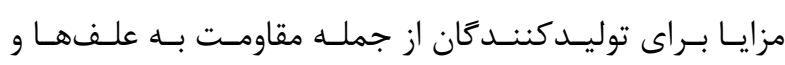
حشرات، مقاومت به خشكى، بهبود مصـرف نيتـروزن، مصـرف

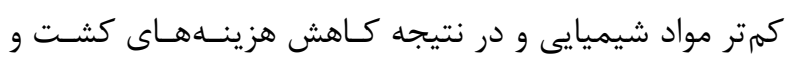

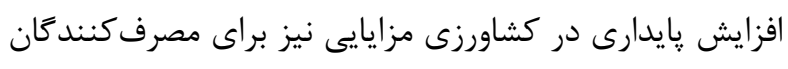

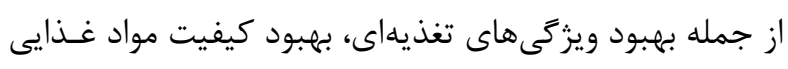

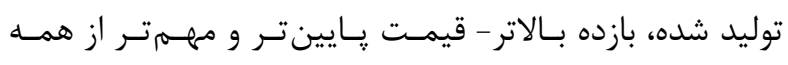

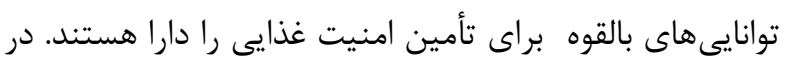

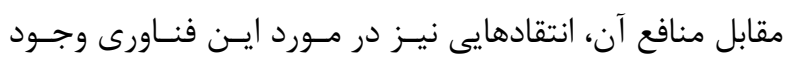

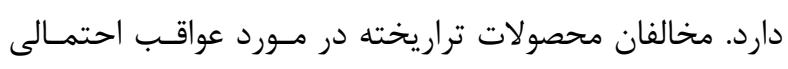

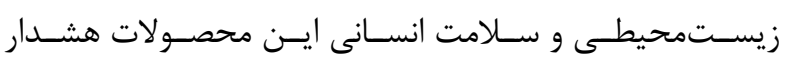
مى دهند. آن ها معتقدند توليد اين محصولات عمدتاً با آلـودگى

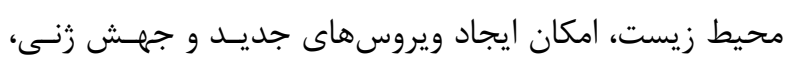

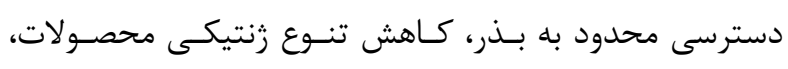

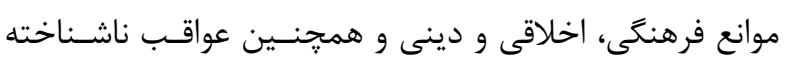

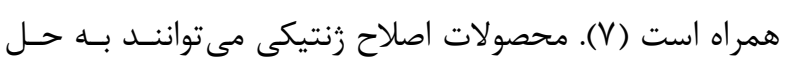

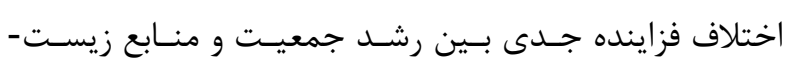
محيطى كمك كنند (1).

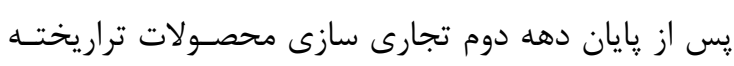

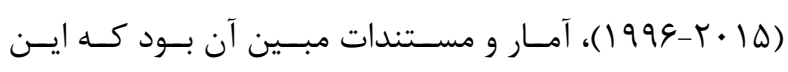
محصولات سود قابل توجهى را در زمينههاى زراعسى، زيست-

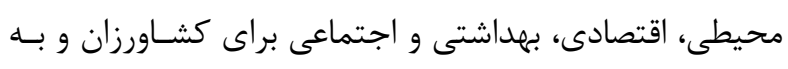

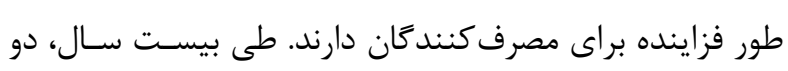

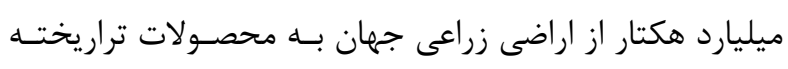

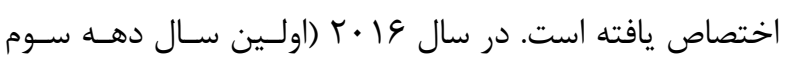
تجارىسازى محصولات تراريخته)، وب كشور جهان، شامل 19

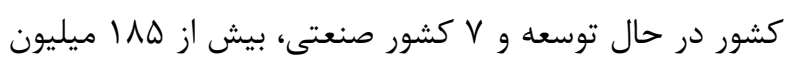

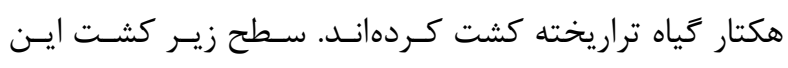

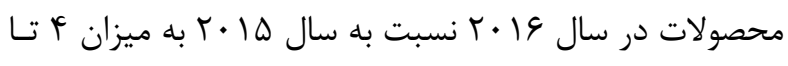
ه ميليون هكتار افزايش يافته است (9).

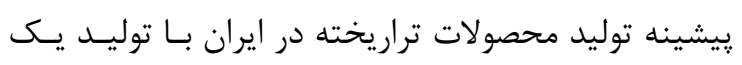

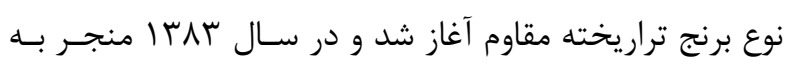

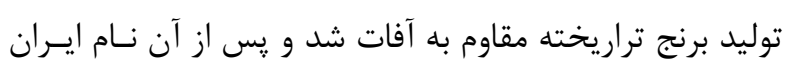

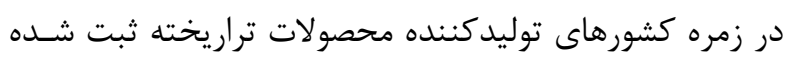

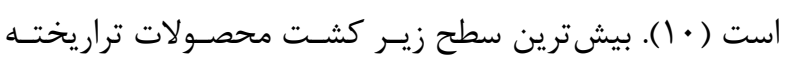

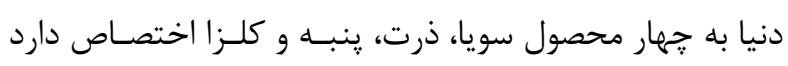

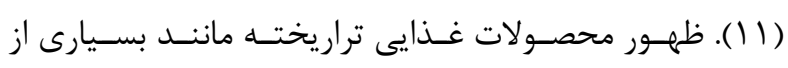
نوآورىهاى ديخر با موافقتها و مخالفتهاى گستردهاى هم در در

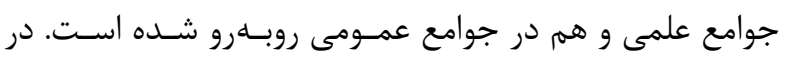
مجامع عملى دنيا از جمله در ايران دو زروه از محققان موافـق رونق 
مطالعات پيشين تهيه شده است. همجنين در صورت لـزوم در

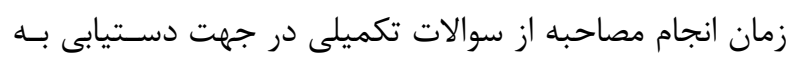
ياسخ جامع استفاده شد (جدول (). ينج مصاحبه قبل از از شروع تحقيق به صورت آزمايشى انجام شد تا جـامع بـودن سـوالات

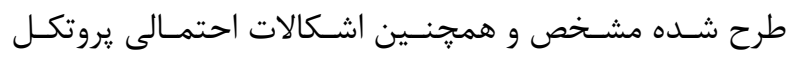
مصاحبه رفع شود و نحوه انجام مصاحبه اصلاح گردد.

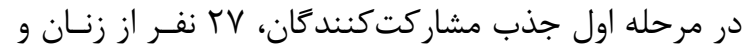
مردان از مناطق مختلف شـهر تهــران وارد مطالعـه شـدند كـهـ

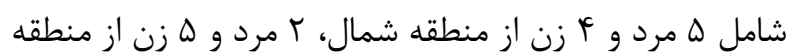

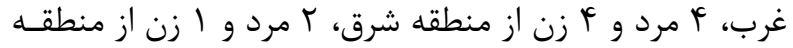

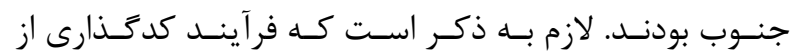
مصاحبه اول به صورت مستمر صورت گرفت و با نوشتن يادآور (Memoing) و كدگذارىها، امكان مقايسه مــداوم را بـا مراجعـه مجـدد بــهـ

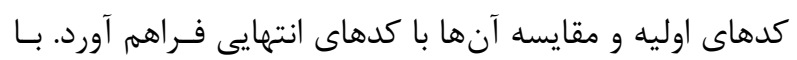

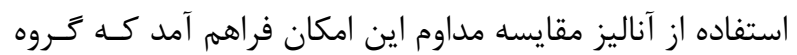
تحقيق از رسيدن به اشباع مقـولات آخـاه شـود. ب نفـر ديخــر

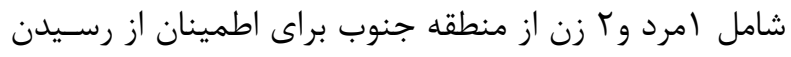

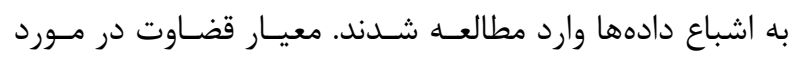
زمان متوقف كردن ورود مشاركت كنندگان جديد، رسـيدن بـهـ اشباع مقولهها بود، بدين معنا كه هـيـج داده بـيشتـرى يافتـ

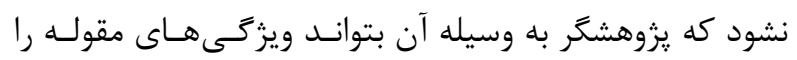
رشد دهد.

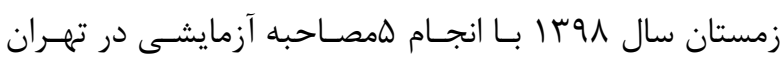
شروع شد و در تابستان سال و\سا با تحليل آناليزهاى صورت كَرفته به يايان رسيد. جامعهى آمارى مورد مطالعه نيز در ايسن

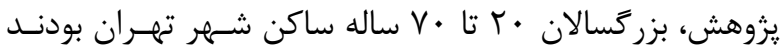

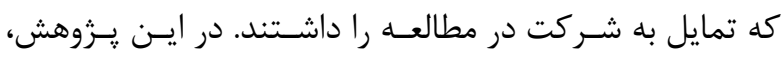
جمع آورى دادهها تا رسيدن به اشباع دادهها ادامه يَيـدا كـرد و

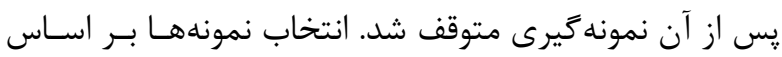
منطقه محل سكونت و با حداكثر تنوع ( Maximum diversity

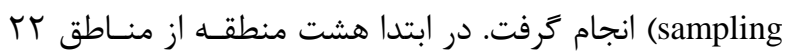
كانه شهر تهران با توجه به مناطق جغرافيايى يعنى از هر كدام

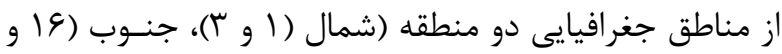

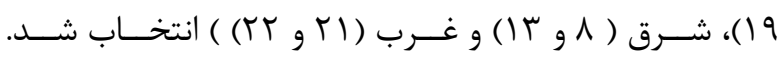
نمونهها از سراىمحله و فرهنگسراها و ياركىهاى ايسن منـاطق

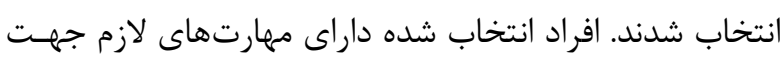

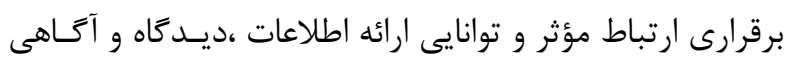

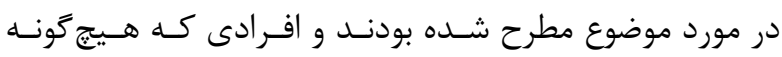

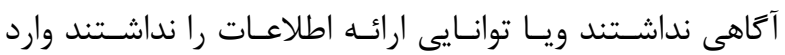
مصاحبه نشدند. يس از دعوت از افراد واجد شرايط سنى، ابتـدا اهداف تحقيق شرح داده و يس از كسب رضايت فـردى، اجـازه انجام و ضبط مصاحبه اخذ مىشد.

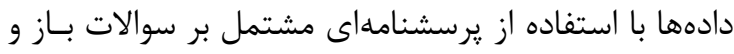

در قالـب مصـاحبه نيمـه سـاختار يافتـه ( Semi Structured جمع آورى شد. سوالات اين يرسشنامه متناسب بـاسـا اهداف مطالعه و با همانديشى تيمم تحقيق و با توجـهـ بـه مــرور

جدول I ـ راهنماى مصاحبه نيمه ساختاريافته با شركت كنندكان در مطالعه

\begin{tabular}{|c|c|}
\hline سوالات تكميلى & سوالات باز مصاحبه نيمه ساختاريافته \\
\hline & در مورد غذاهاى تراريخته ( اصلاح زنتيكى شده) جه اطلاعاتى داريد؟ \\
\hline & ميشه به من بكيد تراريخته جه معنى داره؟ \\
\hline كيفيت & فرق اين نوع محصولات با محصولات غيرتراريخته جيه؟ \\
\hline ظعرم و مزه & فكر ميكنيد جه اتفاقى در مواد غذايى ايجاد ميشه كه ميكن تراريخته شدن؟ \\
\hline ميتونيد קند تا از محصولات تراريخته رو نام ببريد؟ & آيا از محصولات تراريختهاى كه در فروشگاه ها به فروش مى رسند اطلاع داريد؟ \\
\hline اخر بلى، جه نَخرانى؟؟ & آيا شما براى خريد يا مصرف اين نوع محصولات، نخرانى داريد؟ \\
\hline سلامت جسمى روحى & به نظر شما با خوردن غذاهاى تراريخته در بدن ما تغييرى اتفاق مى افتد؟ \\
\hline كدام يك از اين منابع اطلاعاتى براى شما مهمترند؟ & اين اطلاعات را بيشتر از جه منابعى به دست اورديد؟ \\
\hline فنويسن خيكنيد جه نوع اطلاعاتى رو روى اين نوع محصولات & آيا برجسب محصولات تراريخته روى بسته بندى ها را تا به حال ديديد؟ \\
\hline & اگر به غير مواردى كه من از شما پرسيدم، نظر ديكرى داريد، لطفا بفرماييد. \\
\hline
\end{tabular}




\section{روش دستيابى به صحت و استحكام دادهها}

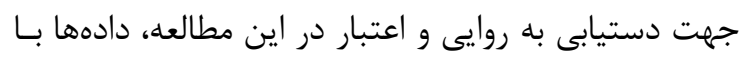

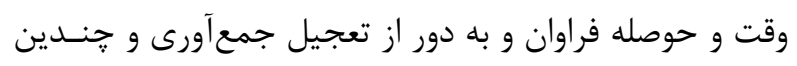

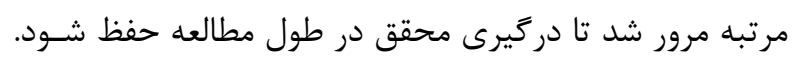

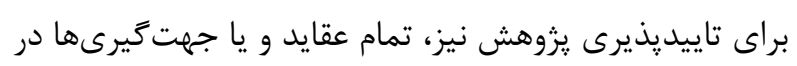

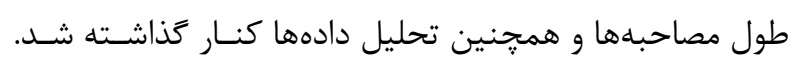

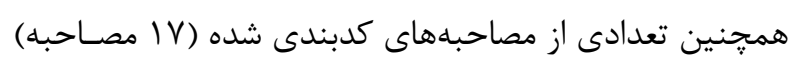

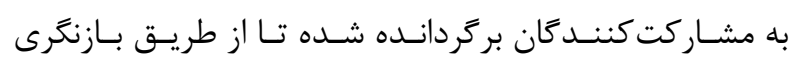

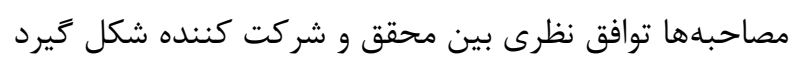
Member Checking)

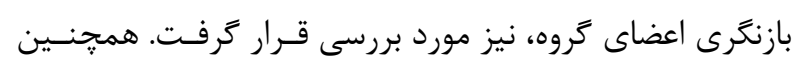

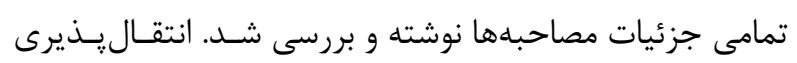

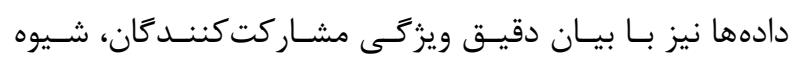

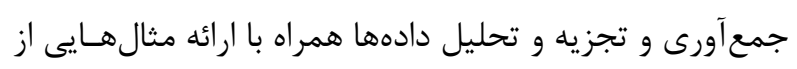

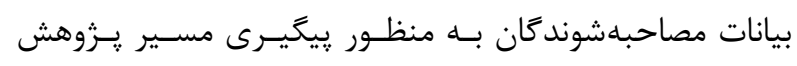

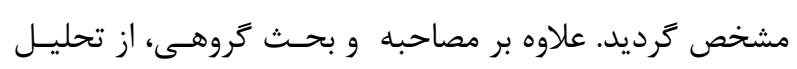
مقايسه مـداوم (Constant Comparative Analysis) اسـتفاده

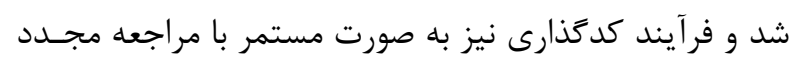

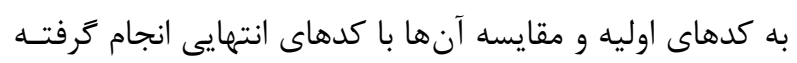

است (19).

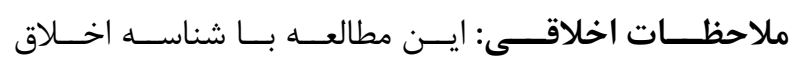

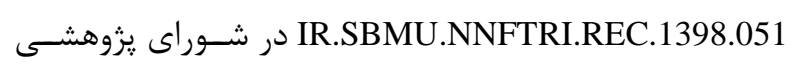

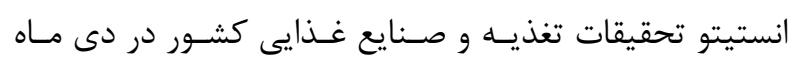

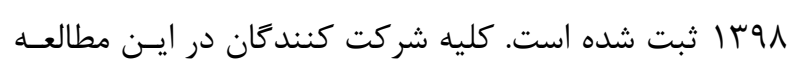

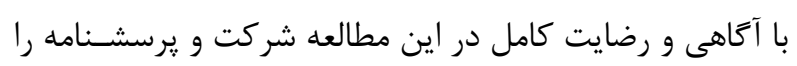

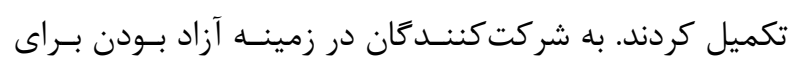

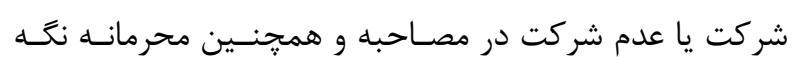

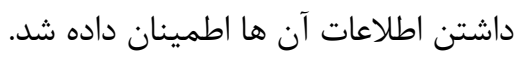

\section{• يافته ها}

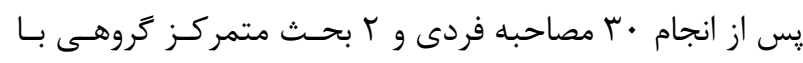

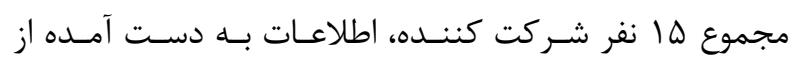

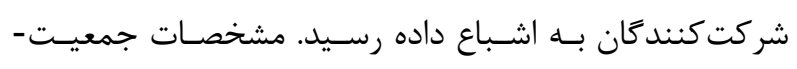

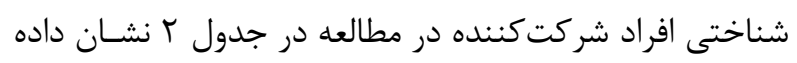

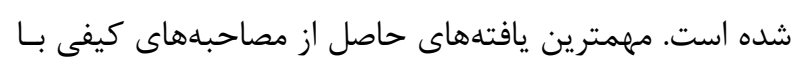

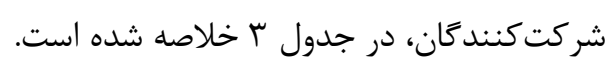

در ابتدا بحثهاى گروهى انجام كرفت، اما با توجه به نتايج

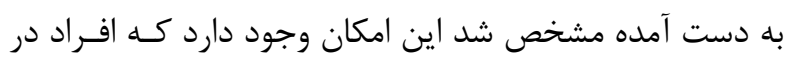

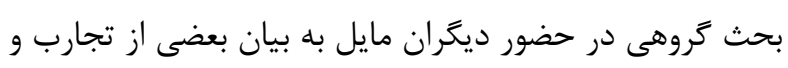

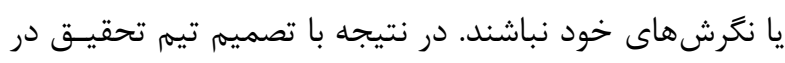

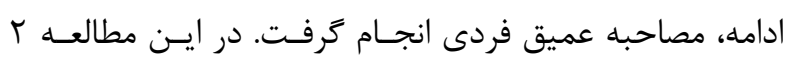

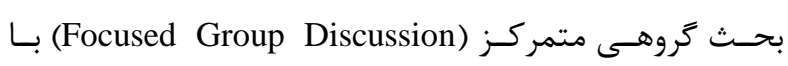

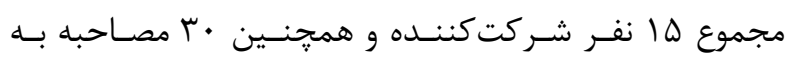
صـورت مصـاحبه عميـق فـردى (In-Depth Interview) نيـز

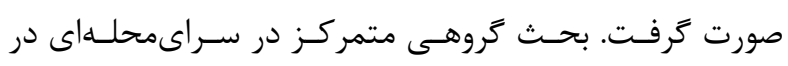

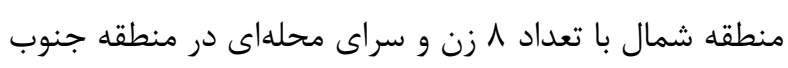

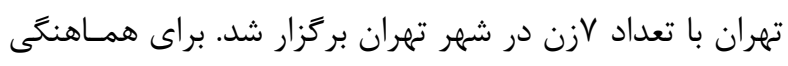

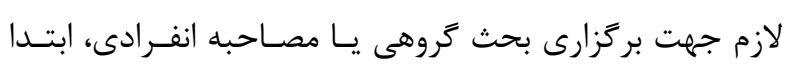

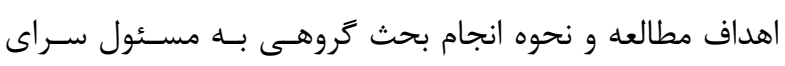

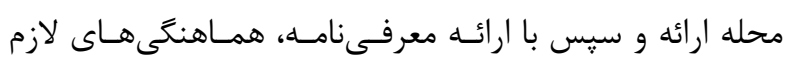

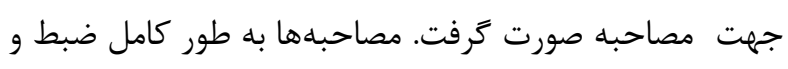

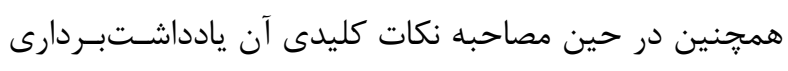

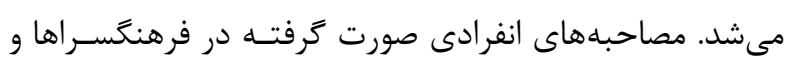

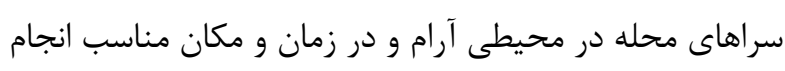

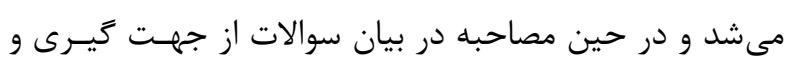

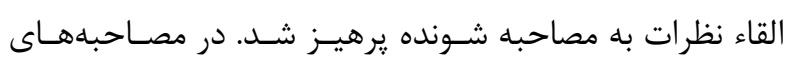

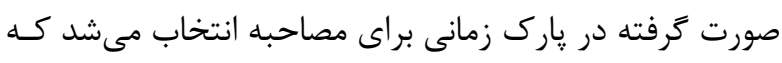

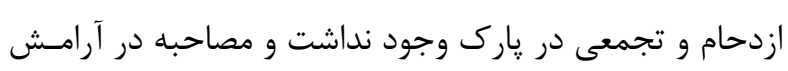

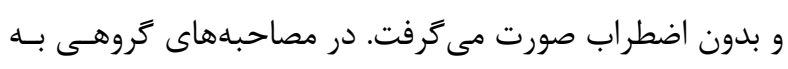

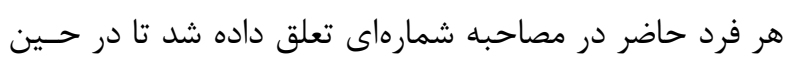

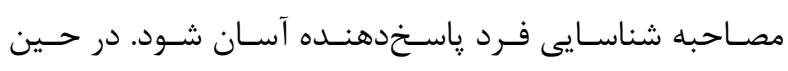

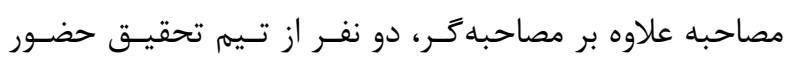

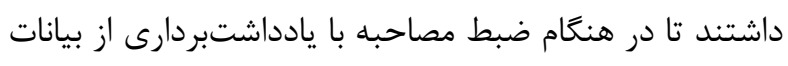

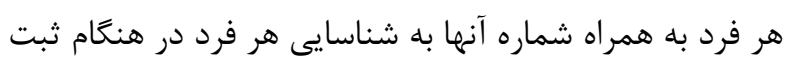

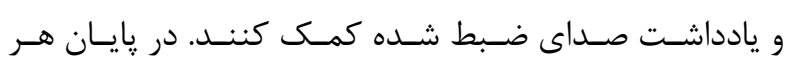

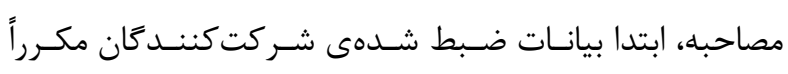

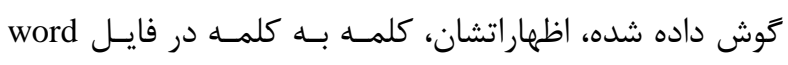

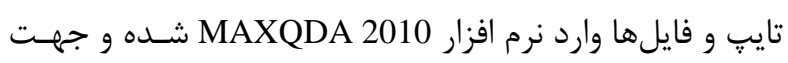

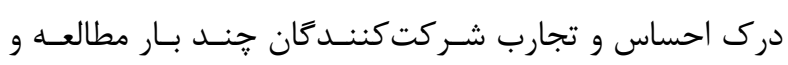
سبس كدكذارى شد. 
جدول r • متغيرهاى جمعيتشناختى شركت كنندكان در مطالعه (تعداد = 1 نفر)

\begin{tabular}{|c|c|c|}
\hline دامنه & ميانكَين \pm انحراف معيار & متغير كمى \\
\hline$r 1-99$ & $r \Delta / V| \pm| \Delta / 9 q$ & سن مصاحبهشوندگان (سال) \\
\hline \multirow[t]{2}{*}{ درصد } & فراوانى ل & متغير رتبهاى \\
\hline & & نوع مصاحبه \\
\hline 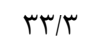 & 10 & كروهى \\
\hline $99 / \mathrm{V}$ & $r$. & فردى \\
\hline $9 / / 9$ & r & زن \\
\hline \multirow[t]{2}{*}{$r M / 1$} & If & 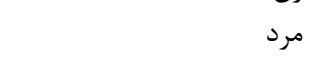 \\
\hline & & ميزان تحصيلات \\
\hline G/V & r & 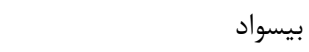 \\
\hline 1/9 & r & ابتدايى \\
\hline$r / /$ & If & سيكل و ديبلم \\
\hline$r / /$ & If & فوق دييلم و ليسانس \\
\hline \multirow[t]{2}{*}{$r T / r$} & 1. & ارشد و بالاتر \\
\hline & & وضعيت تاهل \\
\hline $\mathrm{rV} / \mathrm{V}$ & IV & مجرد \\
\hline$\Delta \Delta / \varphi$ & ro & متاهل \\
\hline G/V & r & بيوه \\
\hline
\end{tabular}

جدول ץ . خلاصه مهمترين يافتههاى حاصل از مصاحبههاى كيفى با افراد شركت كننده در مطالعه

\begin{tabular}{|c|c|c|}
\hline كدهاى باز & طبقات اصلى & \multirow{6}{*}{ درى و برداشت ذهنى مصرفكنندگًان } \\
\hline 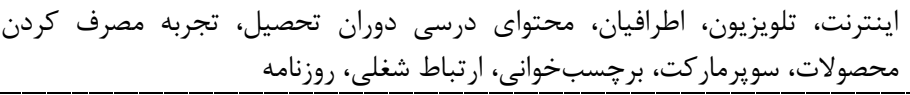 & منابع كسب اطلاعات & \\
\hline 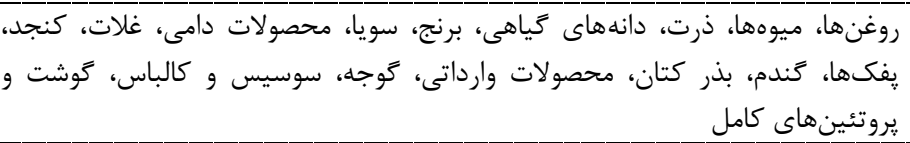 & 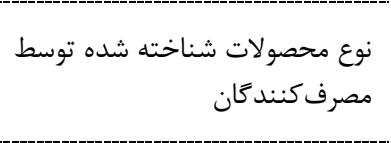 & \\
\hline تبليغ هاى اغراق شده معرفي مناسب محصولات & وضعيت اطلاع رسانى & \\
\hline 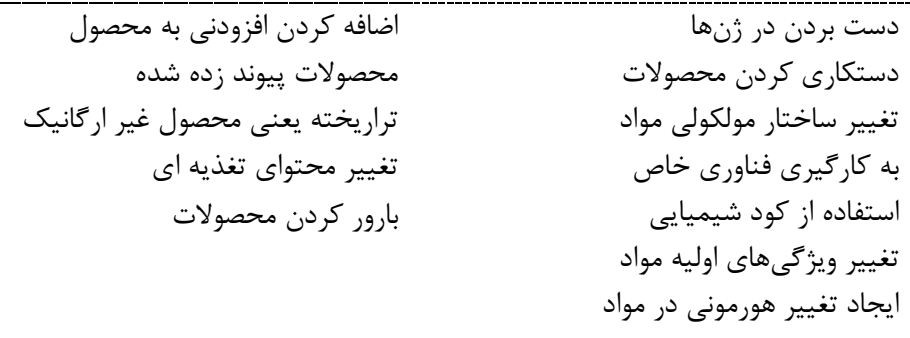 & 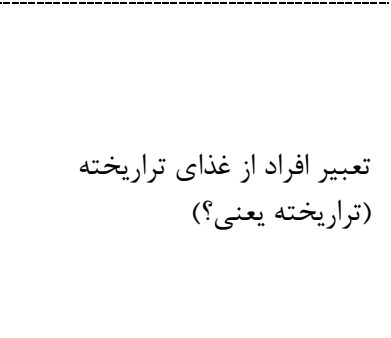 & \\
\hline تفاوت & قياس محصولات عادى و تراريخته & \\
\hline 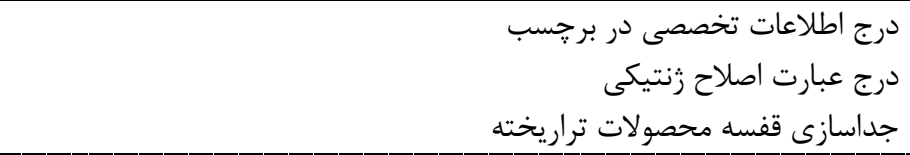 & تراريخته برجس و نشانه مخصوص & \multirow[t]{2}{*}{ 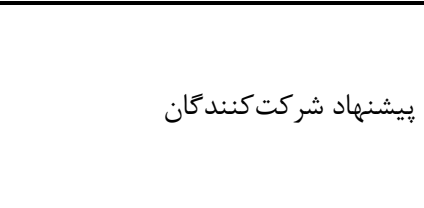 } \\
\hline اجبار اطلاع رسانى در رسانه ها & اطلاعرسانى صحيح & \\
\hline
\end{tabular}




\section{نوع محصولات شناخته شده توسط مصرفكنندكان} از مصاحبه شونده خواسته شد با توجه به اطلاعات خود، محصولات تراريخته موجود در فروشعاهها را معرفى كنند.

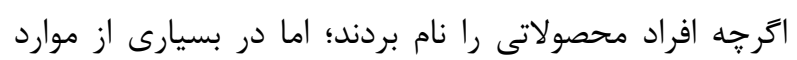

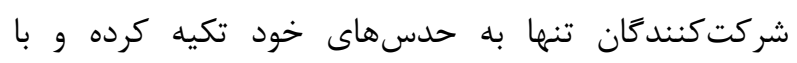
قاطعيت محصولى را معرفى نمى كردند. در مورد ميوهها اين افراد تمام محصولاتى كه اندازهاى بزركتر و حتى رنتى زيباتر و يا طعم و مزه هميشگى را نداشتند به عنوان محصولاتى تراريخته در نظر مى دفعات تكرار به شرح ذيل است: روغن ها، ميوه ها، ذرت، دانههاى زياهى، برنج، سويا، محصولات دامى، غلات، كنجد،

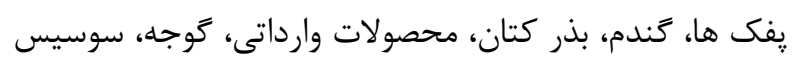

$$
\text { و كالباس، گوشت و يروتئينهاى كامل. }
$$

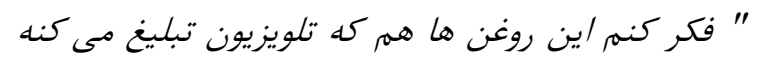
كه ويتامين D دارند /ينها هم دستكارى شله" (آقاى وب ساله)

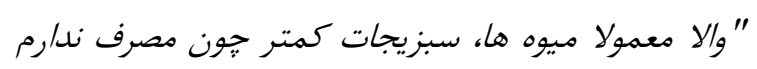

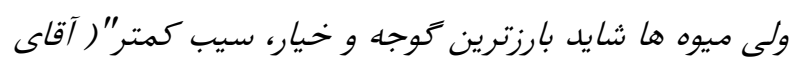
(1) "من توى ميوهها /ستفاده كردم مثنلا كاهاً ميوههايیى هستند كه هم از نظر ظاهرى ميوه زيباتر هم وزن بيشترى مئرى داشته و برام سوال شله و شنيدم كه دستكارى شله ديكه" هئه

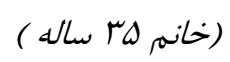

"يه بيامكى /ز كانادا فرستاد بِرم ولى /ين طوركه توضيح

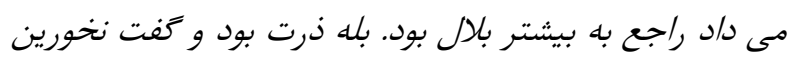

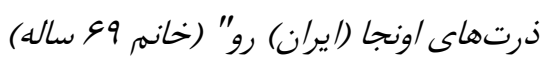

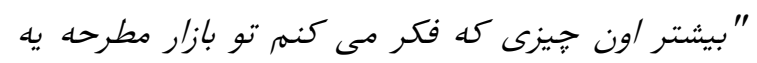

$$
\text { زمانى به برنج حير داده بودن" (آقاى VV ساله) }
$$
"اينايى كه وارداتى هستن /ينايى كه /ز جنين و /ينا وارد

$$
\text { مىكنند اكثراً مى كن تراريخته" (خانم •F ساله) }
$$

\section{وضعيت اطلاع رسانى}

اطلاعرسانى مناسب و صحيح نقشى مهم و تاثيرگذار در ذهنيت و درك مصرفكنندگان دارد. طبق اظهارات صورت

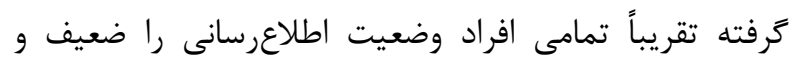
ناكافى مىدانستند. آنها معتقد بودند كه هيج نشانه و وريا برجسبى مبنى بر تراريخته بودن اين محصولات وجود ندارد.

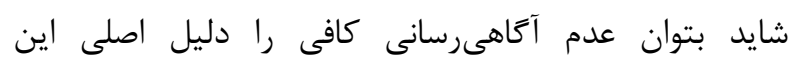
نارضايتى دانست. بيشنهادها براى بهببود وضعيت اطلاع رسانى
با بررسى كدهاى باز جند طبقه اصلى ظهور يافت كه در ذيل به تفكيك مورد بحث و بررسى قرار مى منابع كسب اطلاعات در مورد محصولات تراريخته طبق اظهارات شركت كنند منابع كسب اطلاعات در مورد محصولات تراريخته به ترتيب از طريق اينترنت و تلويزيون بود. ساير موارد ذكر شده عبارت

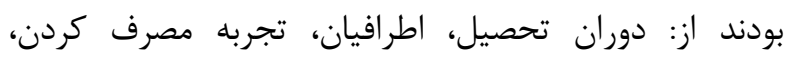
سويرماركتها، برجسبخ توانى، ارتباط شغلى و روزنامه بود. در بسيارى از موارد اخرجه منبع كسب اطلاعات توسط افراد مشاركت كننده بيان مىشد اما با اين حال ميزان اطلاع رسانى انجام شده را ناكافى مىدانستند. با توجه به دادههاى موجود

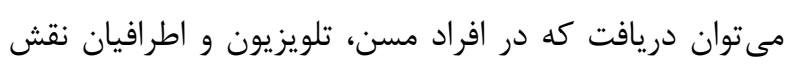

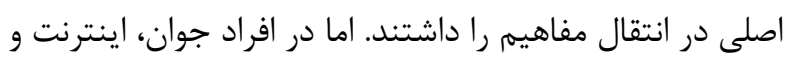
فضاى مجازى مهمترين نقش را ايفا مى كرد. در اظهارت افراد كاملا مشهود بود كه در معرفى محصولات تراريخته به تبليغات

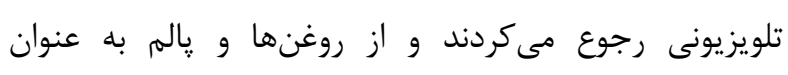
محصولاتى تراريخته ياد مى كردند جرا كه اين دو دور محصول تبليغات كستردهترى دارند و شناخته شدهتر هستند. برخى از اظهارات افراد در ذيل آمده است:

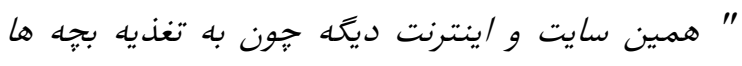
خيلى حساسهم واسه همين سعى مى كنهم تحقيق كنهم" (خانم. ( ) p. " توى بيج / ينستاكر/م عكس ها رو مى بينهم كه مى زنن مى كن جه اتفاقى روى /ينا افتاده"(خانمر ابr ساله)

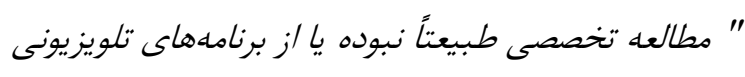

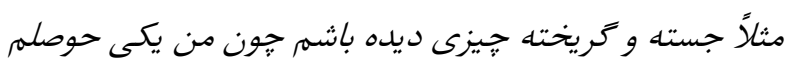
نمى كشه مطالب بلند و بالا بخونه" ( آقاى عV ساله)

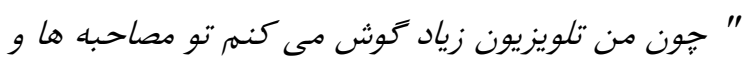

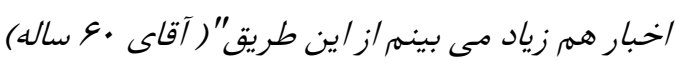

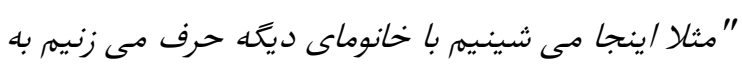
همديكة مى كيهر"(خانم 9 ه ساله)

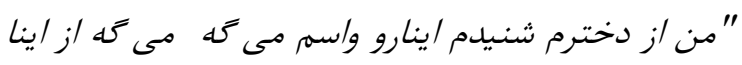
نخريم" (خانم, عو ساله)

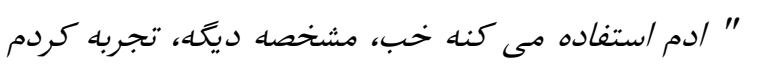
مثلا كلابى /ركانيك خيلى خوشمزه تره و شيرينتر و آبدار تره نسبت به كلابى كه /ركانيك نيست و كاملا مشخصه هورمونيه،

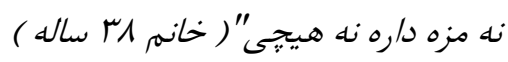


اين طيف مختلف از تعابير اكرجه به درستى بيان كننده

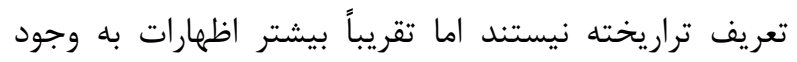

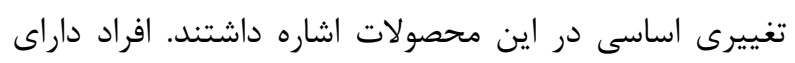

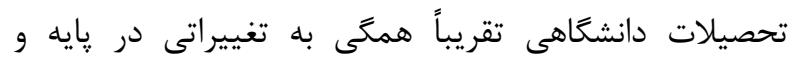

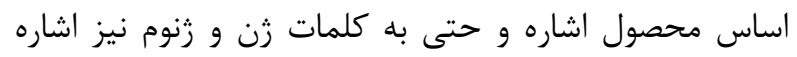
مى كردند. افراد مسن و افرادى با تحصيلات كمتر از تعابيرى مانند ييوند زدن، هورمون زدن، مخلوط كردن، كود شيميايى

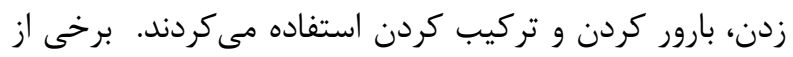
اظهارات افراد در ذيل بيان شده است:

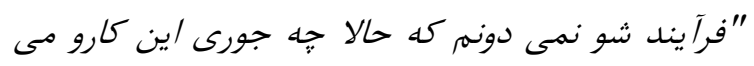

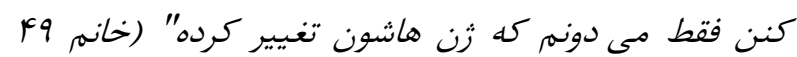

ساله)

"انغار كه يك سرى زن ها رو قاطى مى كنن توى ميوهها

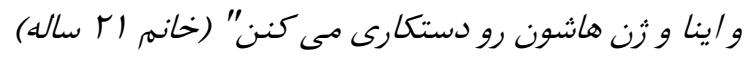

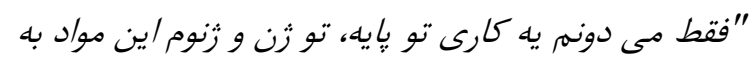

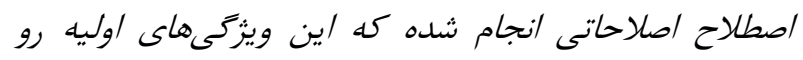
تغيير دادن" (آقاى VV ساله)

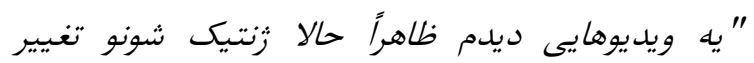

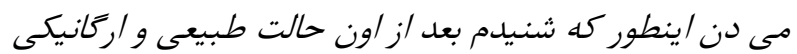
كه هستش خارج مى شه صد در صد يه مضرات خيلى زيادى انسى

$$
\text { هم دارة" (خانم 1) ساله) }
$$

"هيجى فقط مى دونم كه ساختار مولكولى شو عوض (خانم ساله

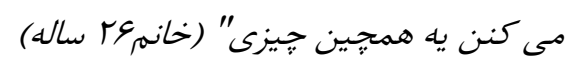

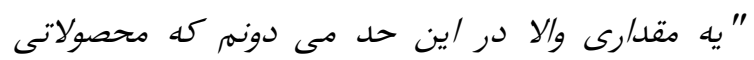

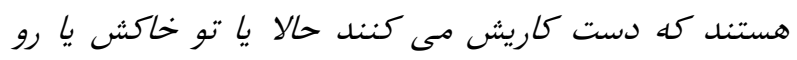
بذرش" (خانم •k ساله) "قطعاً هورمون زدن كه تغيير دادن شكل و اندازه شون رو التالر و قطعا يه اتفاق روشون انجام شده ديكَه كه /ينها تغيير بيدا كردند" (خانم رب ساله) "احتمال مى دم كه مثلاً تركيب مى كنند مثلاً فكر كنيد

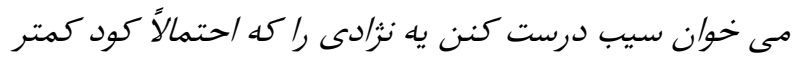

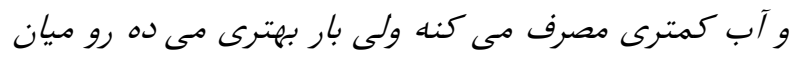
"تلفيق مى كنن" (خانم فr ساله) "بعضى /ز محصولات رو زنتيكى تغيير مى لن /ونارو باهم الماهم

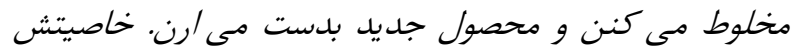
رو عوض مى كنن كه با طبيعت انسان سازكارى نداره (آقاى محنى

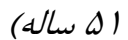

شامل تغيير قفسههاى اين نوع مواد غذايى در فروشگاهها بود،

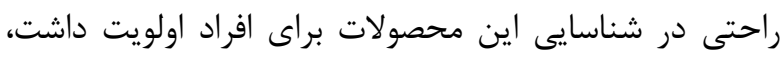

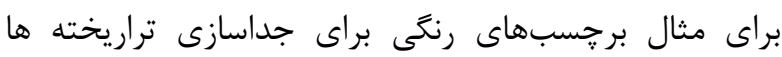
استفاده شود. برخى از افراد از درج راه ارتباطى براى شئى شفاف تراف تراي سازى استقبال مى كردند اما در مقابل بيشتر افراد تنها عبارت تراريخته را براى دادن حق انتخاب به آن ها در هنعام خريد خواستار بودند. اما در كل افراد قبل از اين موضوع، اطلاع

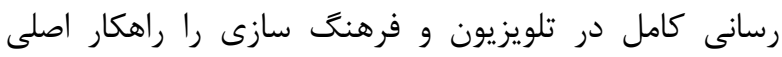
كاهش نكرانى هاى مربوط با محصولات تراريخته مى دانستند.

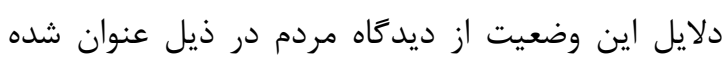

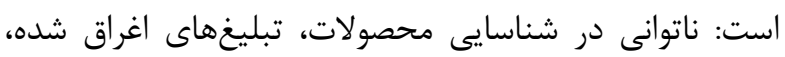

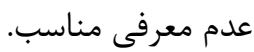
"اخه به ما نمى كن كه كدوماش تراريخته س كه نخريه." (خانم ra ساله)

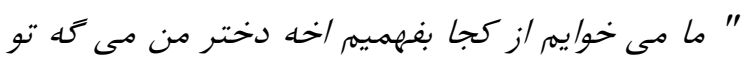

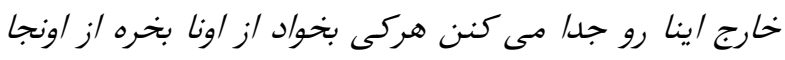
برمى داره" (خانم • له ساله) "الان يه تبليغاتى وجود داره كه / ينها ديكانه خيلى مضراه

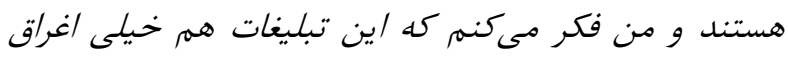

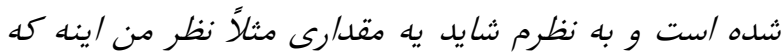

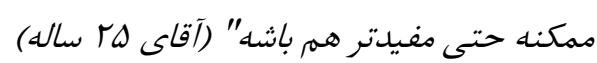

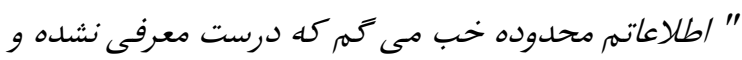

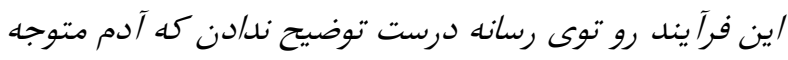
بشه" (خانم qع ساله)

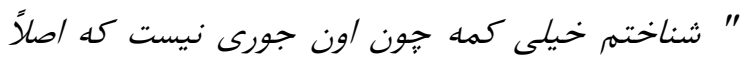

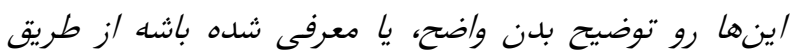
رسانه ها" (خانم وع ساله)

\section{تعبير افراد از غذاى تراريخته (تراريخته يعنى...)} با توجه به نظرات شركت كنند كان در مطالعه، تعابيرى كه افراد در مورد تراريخته بيان نمودند شامل تعابيرى همجون دست بردن در زنها، دستكارى كردن محصولات، تغيير

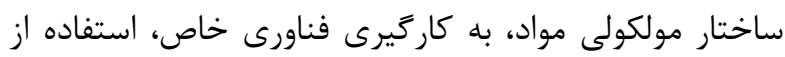

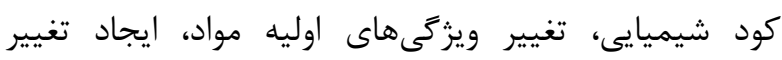
هورمونى در مواد، اضافه كردن افزودنى به محصول، يِيوند زدن، تراريخته يعنى محصول غير اركانيك، تغيير محتواى تغذيه ایى،

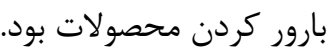


بزركتر بشه به هر حال /ين تغييرات را/يجاد مىكنن به خاطر اين" (خانم آبو ساله)

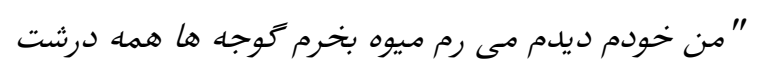

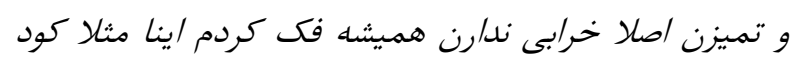

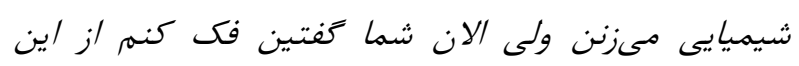

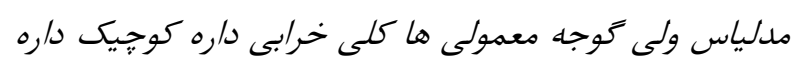
يزرك داره" (خانم او ساله)

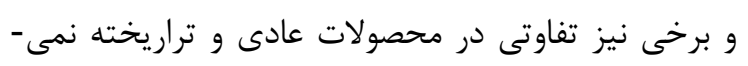

ديدند:

"نمى دونم والا فرقى نمى كنه ولى اركانيك بهتره" (خانم

(

"الزاماً فكر نمى كنهم حتما تو سايز و مزش تغييرى باشه

$$
\text { ولى فكر مى كنهم مفيد نيست (خانم 14 ساله) }
$$

\section{ي يشنههاد شر كت كنندكان}

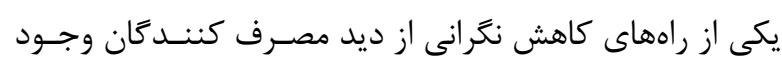

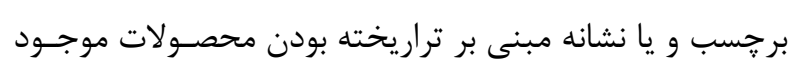

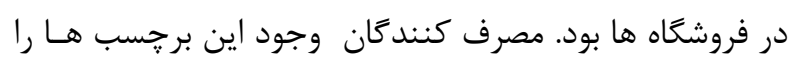

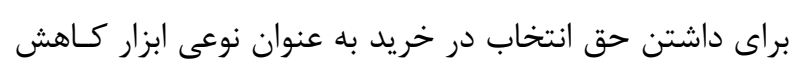
نكرانى مطرح مى كردند. "بله حتما جونكه ما در ظاهرشون نميفهميمى و دوست دارم

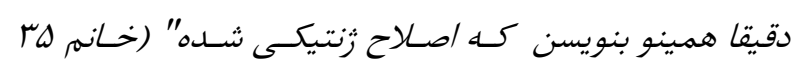
ساله) "صد درصد بايد يه جيزى باشه كه آدم تشخيص بلد، حالا

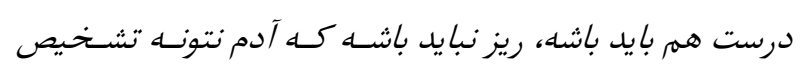

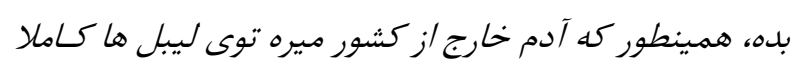
توضيح داده شده" (خانم لها ساله)

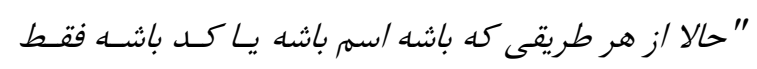

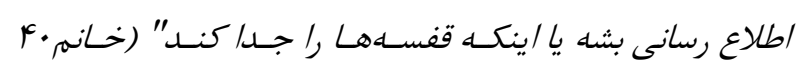
ساله)

طبق اظهارات افراد، آنها دليل اين همه سردر مَمى و شـى

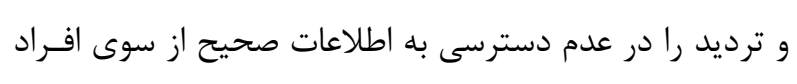

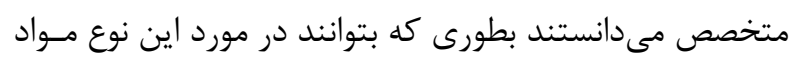
غذايى و تصميم به انتخاب آنها راه درست را انتخاب كنيند.

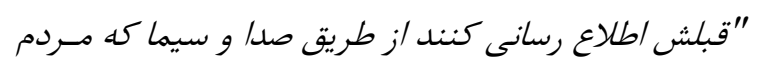

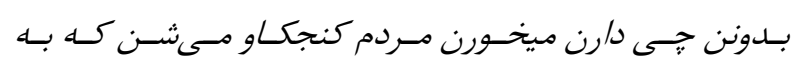
برجسبها دقت كنند" (آقاى rr ساله)

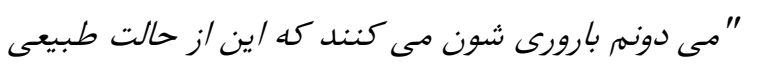
خارج مى شه و ديًَه طبيعى نيستن" (آقاى ؤه ساله)

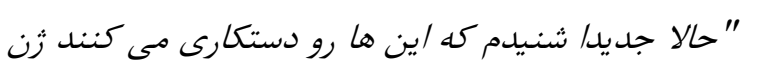

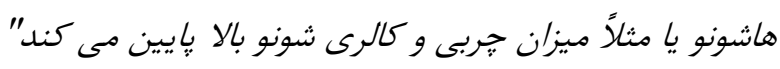
(آقاى عr ساله)

\section{قياس محصولات عادى و تراريخته}

طبق اظهارات بيان شده مهمترين تفاوت ميان محصولات مرات

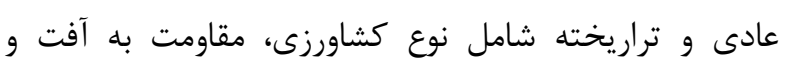

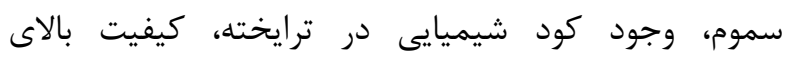

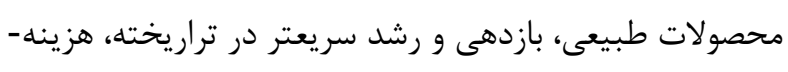

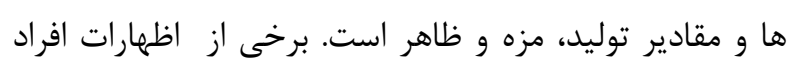

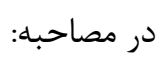
"اينكه به نظرم محصولات عادى كشاورزى سنتى هستش

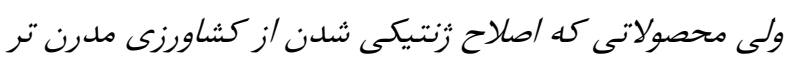
هستند" (خانم ar ساله)

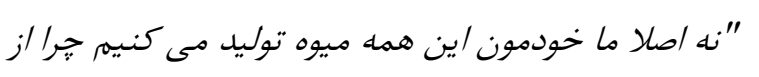

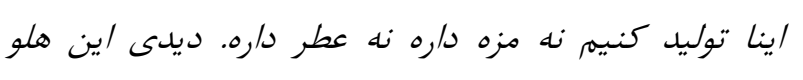

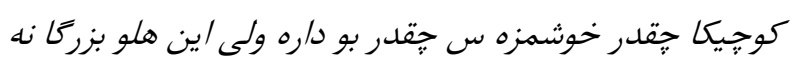
طعمر داره نه مزه نه عطر به درد نمى خوره" (خانم 9 ه ساله)

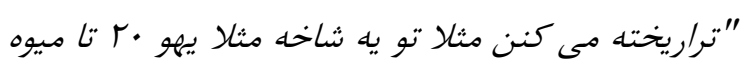

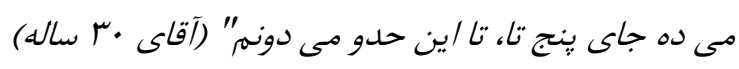

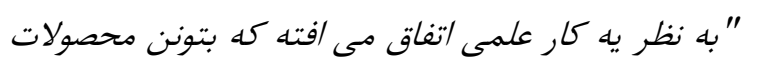

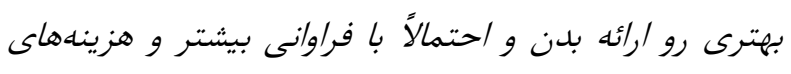
كمتر "آ(آقاى VV عاله)

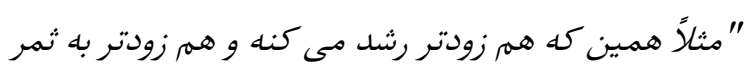
مىرسن" (آقاى هr ساله) بيشترين موارد ذكر شده مربوط به تفاوتهاى مزه و ظاهرى بين محصولات عادى و تراريخته بود مانند:

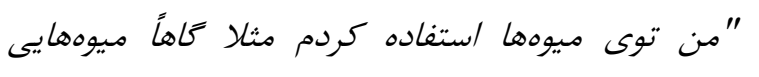

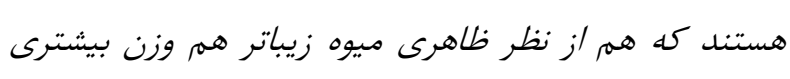

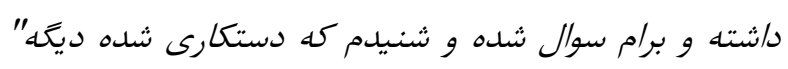
(خانم ها" ساله)

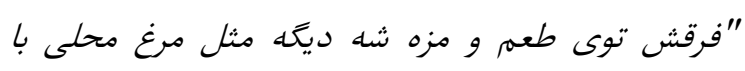
هورمونى كيفيتش فرق مى كنه" (خانمر عr ساله)

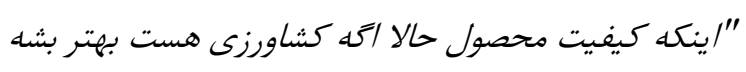

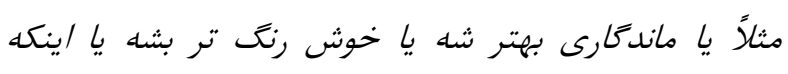




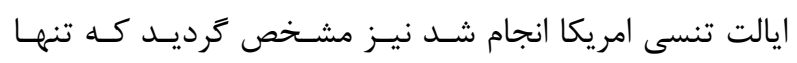

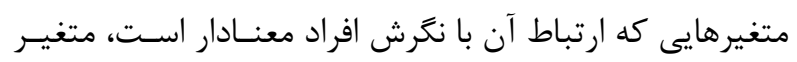

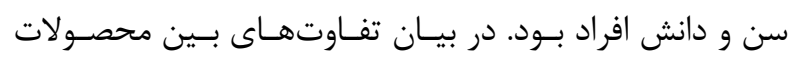

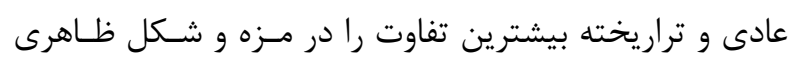

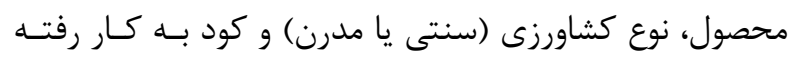

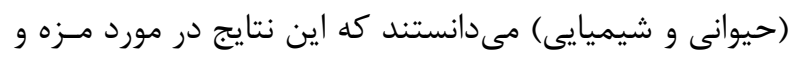

نوع كشاورزى با مطالعه حاضر همخوانى دارد (· (T).

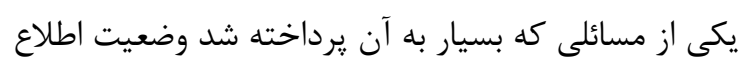
رسانى و ناتوانى در شناسايى و شناخت محصولات تراريخته در

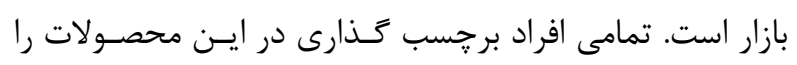
امرى ضرورى مى دانستند. در مطالعهاى صورت گرفته در سـال

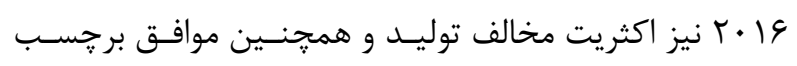

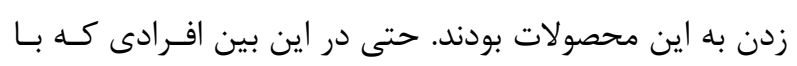

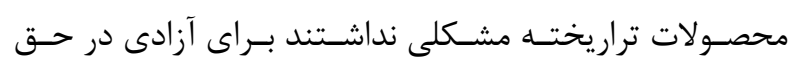

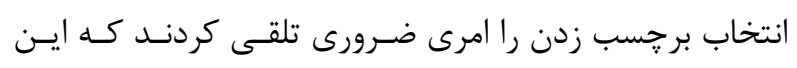

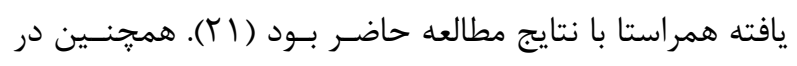

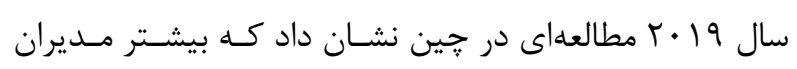

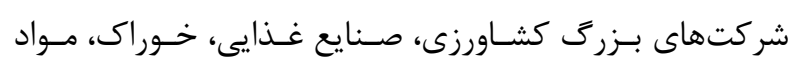

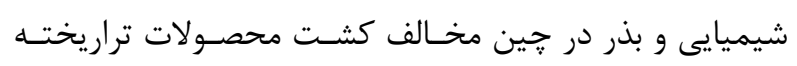

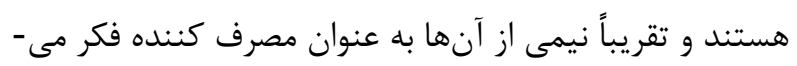

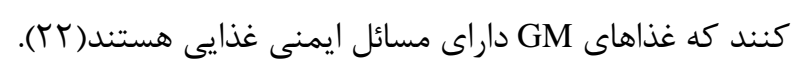

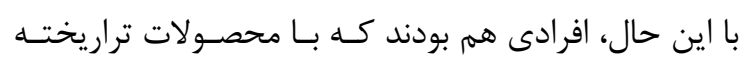

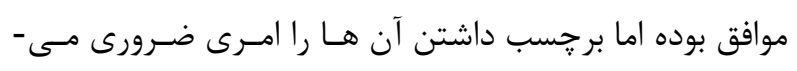

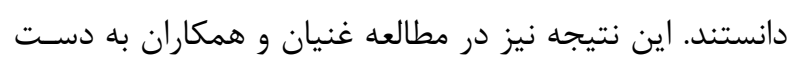

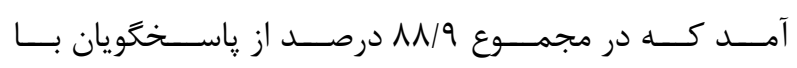

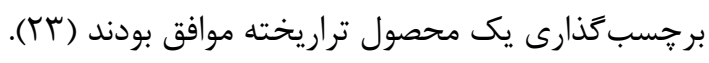

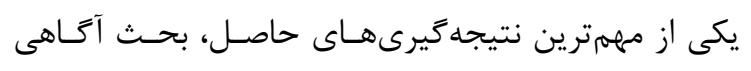

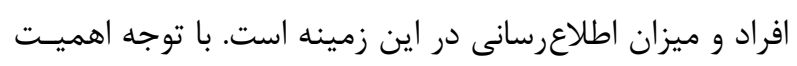

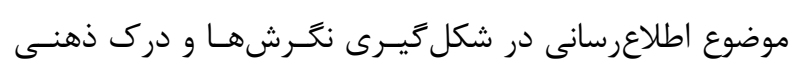

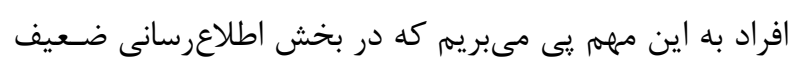
عمل شده است. اين ضعف را مىتـوان در عـدم وجــود تعـابير

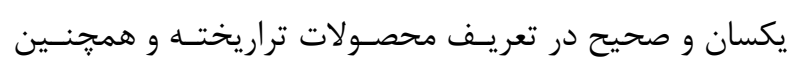
عدم شناخت محصولات تراريخته بازار دانست.

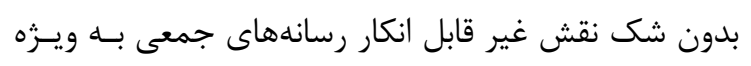

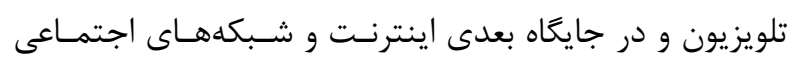

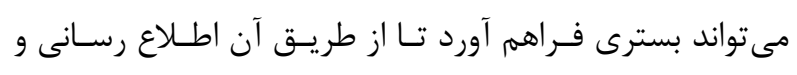

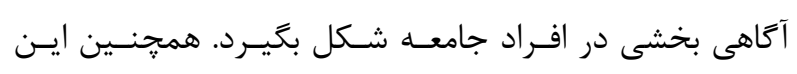

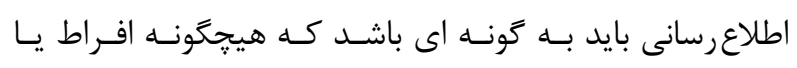

شناخت برداشت و درك ذهنى مصـرفكنــدكان و اينكـهـ

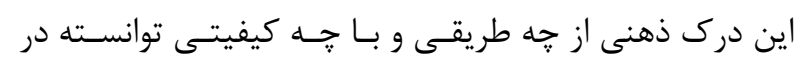

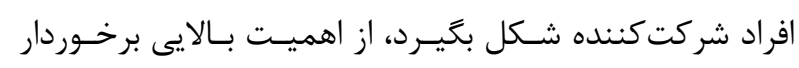

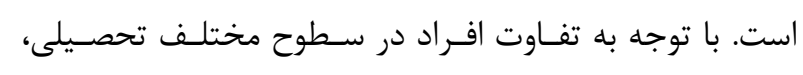

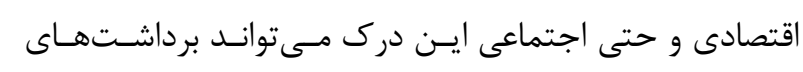

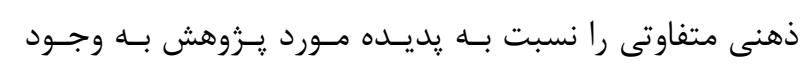

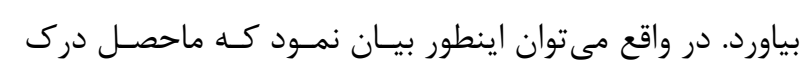

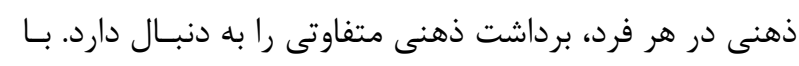

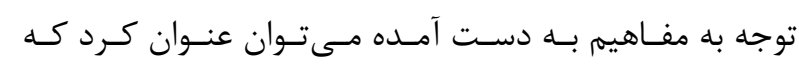

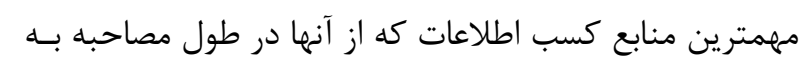

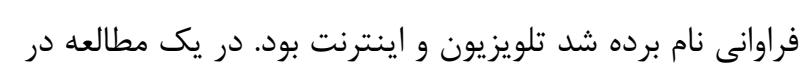

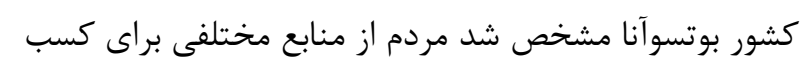

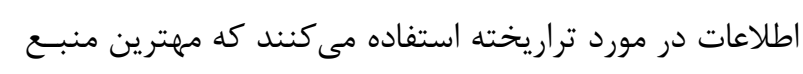

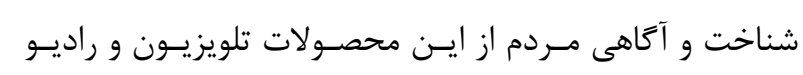

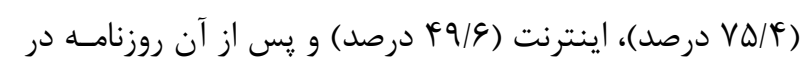

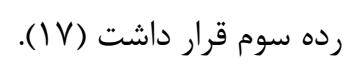

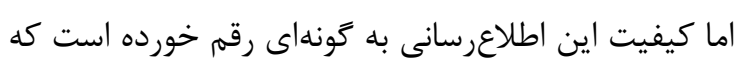

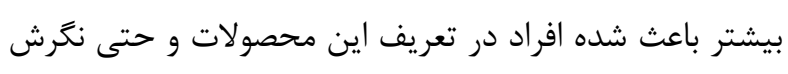

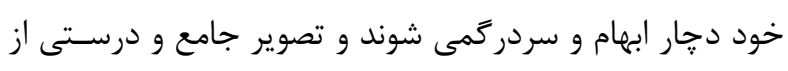

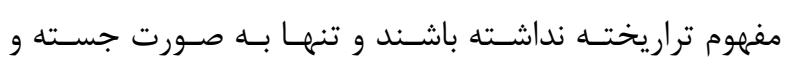

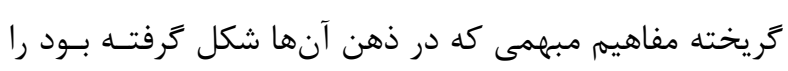

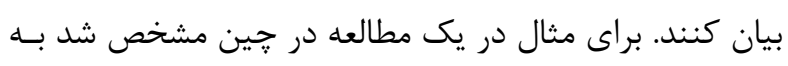

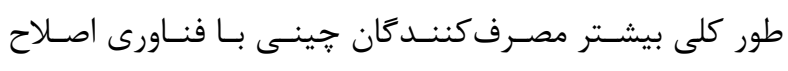

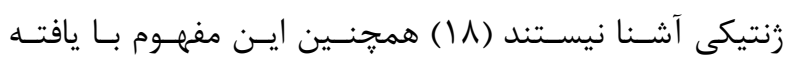

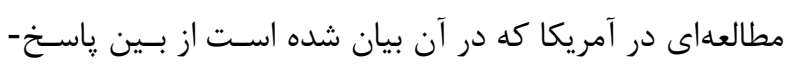

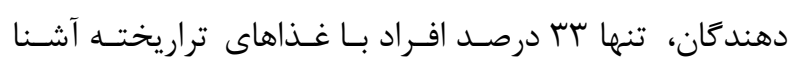

بودند، همخوانى دارد (9 (1) ).

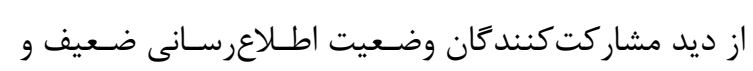
ناكافى بود. دليل اين ضعف را مى توان اين كونه بيان نمود كـهـ

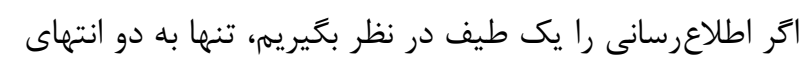

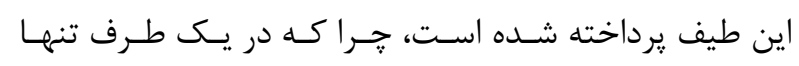

تبليغات مخالف و طرف ديخر تبليغات موافق بيان مىشوند.

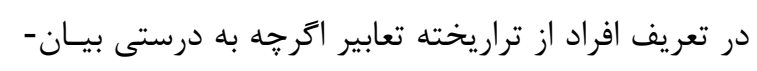

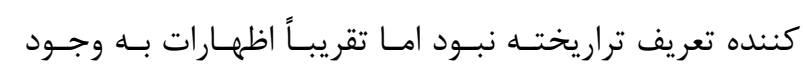

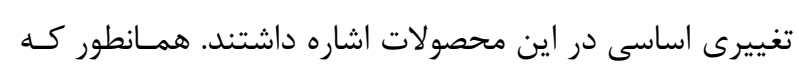

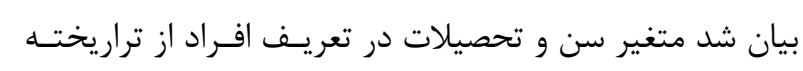

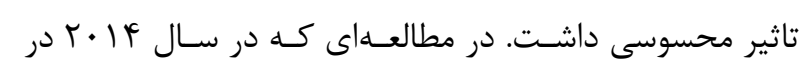




$$
\begin{aligned}
& \text { در سطح شهر تهران و در جهار منطقه جغرافيايى آن انجام شد، } \\
& \text { حضور در مناطق مختلف و يافتن افرادى كه مايل به مشـاركت }
\end{aligned}
$$

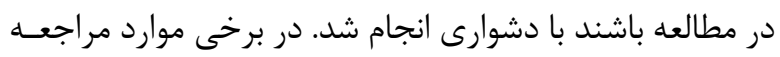

$$
\begin{aligned}
& \text { به ميادين تره بار و فرهنخسر اها با ممانعت مسئولين اين مراكـز } \\
& \text { روبرو شد. }
\end{aligned}
$$

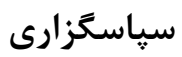

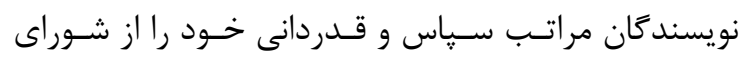

$$
\begin{aligned}
& \text { يزوهشى انستيتو تحقيقات تغذيه و صـنايع غـذايى كثــور بـهـ } \\
& \text { جهت تصويب اين طرح تحقيقاتى ابراز مىدارنـد. همجنــين از }
\end{aligned}
$$

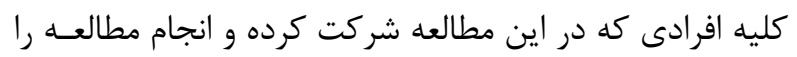

$$
\begin{aligned}
& \text { مقدور ساختند، تشكر و سياسگًارى مىنمايند. }
\end{aligned}
$$

\section{- References}

1. Evans A. The feeding of the nine billion: global food security for the 21 st century. Chatham Historical Society Incorporated, 2009.

2. Godfray HC, Beddington JR, Crute IR, Haddad L, Lawrence D, Muir JF, Pretty J, Robinson S, Thomas SM, Toulmin C. Food security: the challenge of feeding 9 billion people. Science. 2010; 327(5967):812-،8.

3. Verlee D, De Janvry A, Sadoulet E, Townsend R, Klytchnikova I. World development report 2008: agriculture for development. The World Bank; 2008.

4. Statistics FA. Food and Agriculture Organization of the United Nations. Retrieved. 2010; 3(13):2012.

5. Kajale DB, Becker TC. Effects of information on young consumers' willingness to pay for genetically modified food: Experimental auction analysis. Ecology of food and nutrition. 2014; 53(3):292-311.

6. Mohamadian, M. J., V. Aali, M. Saffarioun, R. Khalilzadeh and N. Maghsoudi (). Public Perception in Biotechnology in a Statistical population. Proceeding of 2nd National I. R. Iran Biotechnology Conference: 20011292-1300. [In Persian].

7. Yazdanpanah M, Forouzani M, Bakhtiyari Z. Investigating the Tendency of Khuzestan Province Organization of Agriculture Jihad Experts towards Genetically Modified Crops. Iranian Agricultural Extension and Education Journal 2016; 12 (1): 103-117 [In Persian].

8. Han F, Zhou D, Liu X, Cheng J, Zhang Q, Shelton AM. Attitudes in China about crops and foods developed by biotechnology. PloS one. 2015; 10(9):e0139114.

9. James C. ISAAA Briefs BRIEF 44. Global Status of Commercialized Biotech / GM Crops. ISAAA Br [Internet]. 2012;41(44):2009-2009.

10. Pouresmaeili A, Vaezi Kakhki MR, Bameri E. A Comparative Study of the Consumers Rights of GM

$$
\begin{aligned}
& \text { تفريطى جه در بيان مخالفتها و جه در بيـان موافقـتهــا بــه } \\
& \text { افراد جامعه تحميل نشود. بسط اين مطالعه به ساير استانها، با } \\
& \text { توجه به گستردگى ايران و وجود فرهنگَها و خرده فرهنَهاى }
\end{aligned}
$$

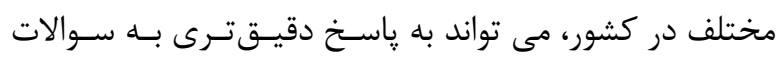

$$
\begin{aligned}
& \text { يزوهش حاضر ارائه نمايد. }
\end{aligned}
$$

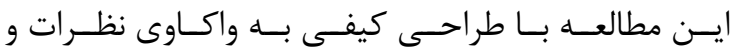

$$
\begin{aligned}
& \text { برداشتهاى ذهنى مصرف كنندگان يرداخته است. اهميت يى } \\
& \text { بردن به اين برداشت و دادههاى ذهنـى موجـود مسىتوانـد بــه } \\
& \text { برنامه ريزى سياست كذاران كمك شايانى كند. } \\
& \text { از محدوديتهاى اين مطالعه مى توان به همكارى نكـردن رئ }
\end{aligned}
$$

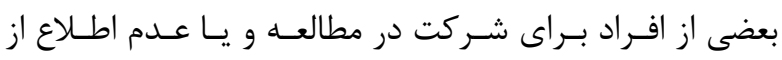

$$
\begin{aligned}
& \text { موضوع مورد تحقيق اشاره كرد. با توجه به اينكه مطالعه حاضر }
\end{aligned}
$$

Crops in Iran and European Union. Bioethics Journal 2017; 7(24): 99-114.

11. Rahnama $H$. Bioethics and transgenic crops production. Ethics in Science \& Technology 2008; 3 (12): 1-14 [In Persian].

12. Nourizadeh M, Kalantari E, Habiba S. Modeling of Tehran Residents Attitude to GMFs Using Structural Equations. Journal of Science \& Technology Policy 2018; 9 (4): 71-84 [In Persian].

13. Magnusson MK, Hursti UK. Consumer attitudes towards genetically modified foods. Appetite. 2002; 39(1):9‘24.

14. Aerni P. Stakeholder attitudes towards the risks and benefits of genetically modified crops in South Africa. Environmental Science \& Policy. 2005; 8(5):464،76.

15. McFadden BR, Lusk JL. What consumers don't know about genetically modified food, and how that affects beliefs. FASEB J. 2016;30(9):3091-6.

16. Bazhan M, Kalantari N, Keshavarz‘Mohammadi N, Eini‘Zinab H, Hosseini $\mathrm{H}$. Exploring the facilitating factors affecting functional dairy products' consumption from the view point of stakeholders: a study based on social marketing theory. Iranian Journal of Nutrition Sciences \& Food Technology. 2018; 13 (3):27،38.

17. Hulela K, Maruapula SD, Peters S. Consumer Knowledge and Perceptions Regarding Genetically Modified Foods: A Case Study of Two Cities in Botswana. Gene Technol. 2020, 9:1. Doi: 10.35248/2329-6682.20.9.149

18. Kai Cui and Sharon P. Shoemaker. Public perception of genetically-modified (GM) food: A Nationwide Chinese Consumer Study. npj Science of Food. 2018, 2:10; doi:10.1038/s41538-018-0018-4

19. Baumblatt JAG, Rand Carpenter L, Wiedeman C, Dunn JR, Schaffner W, Jones TF. Population survey of attitudes and beliefs regarding organic, genetically 
modified, and irradiated foods. Nutr Health. 2017; 23(1):7-11.

20. Vecchione M, Feldman C, Wunderlich S. Consumer knowledge and attitudes about genetically modified food products and labeling policy. Int J Food Sci Nutr. 2015; 66(3):329-35.

21. Rzymski P, Królczyk A. Attitudes toward genetically modified organisms in Poland: to GMO or not to GMO? Food Security. 2016; 8(3):689-97.
22. Haiyan Deng, Ruifa Hu, Carl Pray .2 and Yanhong Jin. Perception and Attitude toward GM Technology among Agribusiness Managers in China as Producers and as Consumers. Sustainability. 2019, 11, 1342; doi:10.3390/su11051342

23. Mehrab-Ghoochani O, Ghanian M, Baradaran M. Analysis the factors influencing specialists' attitudes towards Iranian genetically modified rice. Iranian Agricultural Extension and Education Journal 2017; 12 (2): 53-72 [In Persian]. 


\title{
Consumer Perceptions toward Genetically Modified Food Products: A Qualitative Study in Tehran
}

\author{
Zare Bidaki $S^{1}$, Mirzay Razaz $J^{2}$, Haghighian Roudsari $A^{3 *}$
}

1-MSc in Nutritional Science, Faculty of Nutrition Science and Food Technology, National Nutrition and Food Technology Research Institute, Shaheed Beheshti University of Medical Sciences, Iran.

2-Assistant Professor, Department of Community Nutrition, Faculty of Nutrition Science and Food Technology, National Nutrition and Food Technology Research Institute, Shaheed Beheshti University of Medical Sciences, Iran.

3-*Corresponding author: PhD in Nutritional Science, Department of Community Nutrition, Faculty of Nutrition Science and Food Technology, National Nutrition and Food Technology Research Institute, Shaheed Beheshti University of Medical Sciences, Iran. Email:ahaghighian@yahoo.com

Background and Objectives: Currently, increases in population of the world increase supply and food demands. Production of transgenic plants is one of the relative achievements. The aim of this study was to describe the consumer perceptions towards transgenic products.

Materials \& Methods: The study was carried out by sampling with the maximum diversity and participants enrolled until data saturation. Thirty adults aged 20-70 years living in Tehran were recruited in the study using in-depth interviews and 15 people were included in the study through focus group discussion. Data were analyzed using directed content analysis and MAXQDA Software (Version 10).

Results: Findings showed that people awareness on transgenic products was relatively low and limited. The sources of information mostly included the Internet and television and the most important types of transgenic products were oils, fruits, corn, rice and soy. Based on the participant views, lack of exact determination criteria and exaggerated advertisements were the shortcomings of information on these products. Based on the consumer interpretation, transgenic foods were products manipulated by hormonal changes and molecular structure grafts, which included various tastes and appearances, compared to normal products.

Conclusion: Based on the importance of information in shaping people attitudes and perceptions, lack of proper information to publicity was revealed in this study. Proper use of the undeniable ability of mass media, especially television, is one of the factors that can contribute to this information. Another factor that can help this information includes clear labeling.

Keywords: Genetic modification, Transgenic plants, Perception, Consumer, Qualitative study 